\title{
Enzymatic Adaptations by Cultured Adipocytes of Human Infants and Children: Effect of Obese Serum on the Activities of Lactate-, Malate-, and Glucose-6-phosphate Dehydrogenases
}

\author{
FESTUS O. ADEBONOJO ${ }^{37}$ \\ Children's Hospital of Philadelphia, Rebound Health Center, and The University of Pennsylvania School of \\ Medicine, Philadelphia, Pennsylvania, USA
}

Extract

To determine whether there are any biochemical characteristics which distinguish human adipose cells from human skin fibroblasts, assays of lactate dehydrogenase with pyruvate as substrate ( $\mathrm{LDH}-\mathrm{P})$, malate dehydrogenase $(\mathrm{MDH})$, and glucose-6-phosphate dehydrogenase (G6PDH) were done on both cell types after they had been successfully adapted to artificial medium in tissue culture and also while they were growing temporarily in serum from an obese individual. After undergoing transformation to a fibroblastlike appearance, the adipose cells (adipofibroblasts) contained significantly more of each enzyme than did the initial adipose cell isolates. The level of activities of $\mathrm{LDH}-\mathrm{P}$ and G6PDH increased to the same levels as in skin fibroblasts (Table 2); however, MDH activities rose to much higher levels than those found in skin fibroblasts (Table 2 ).

In obese serum, activities of LDH-P did not significantly change but the activities of $\mathrm{MDH}$ and G6PDH dropped sharply in adipofibroblasts $(P<0.005$, Table 2 and Fig. 5), whereas in cultures of skin fibroblasts, only the activities of G6PDH dropped significantly ( $P<0.025$ Table 2 ), the other enzyme activities being unchanged. It is concluded that, on the basis of the biochemical behaviors of these two cell lines in culture, adipose cells are biochemically different from skin fibroblasts and are not to be regarded as just fibroblasts with lipid-storing ability.

\section{Speculation}

Some evidence suggests that adipose cells are derived from stromal precursors present in the adipose depot. The data presented in this study suggest that, although cultured adipose cells may be similar in some respects to skin fibroblasts, they have some important differences from skin fibroblasts. The differences may reflect the fact that, as a consequence of differentiation, enzymatic patterns develop which determine how they will perform their special functions of lipid synthesis, storage, and release. It is argued that adipocytes and their precursors are not fibroblasts which happen to be able to store lipids.

Assays of many NAD-dependent enzymes have been done on adipose tissue from obese and nonobese animals $(6,10,12,13,18$, $19,21,33,35)$ and human adults and children $(7,8,23,29)$. For example, the activities of lactate dehydrogenase (EC 1.1.1.27) in adipose tissue of many species appear to parallel those in man (7, 29, 33). The activities of malate dehydrogenase (EC. 1.1.1.37) and glucose-6-phosphate dehydrogenase (EC. 1.1.1.49) have been higher in adipose tissue of pigs $(12,13)$ than in similar tissue of other species (6-8, 18, 19, 21, 23, 29, 33, 35). Novak et al. (23) have found G6PDH to be absent from adipose tissue of adult humans but present in significant quantities in the adipose depot of the newborn in the first 3 days after birth, after which it disappears.

Attention has focused recently on two enzymes in the adipose tissue, G6PDH and MDH. These enzymes are important in the coupling of glucose metabolism to the synthesis of fatty acids because both are involved in a series of different metabolic steps which result in the generation of fatty acid precursors from glucose and the production of NADPH specifically required in fatty acid synthesis. Each of these enzymes appears to be more active in the adipose tissues of obese animals than in the depots of nonobese $(12,13,21)$. Han and Skala (10) have shown that in the weanling rat during the first 6 weeks of life the level of activities of $\mathrm{MDH}$ is fairly constant in the brown fat whereas it rises moderately and progressively in the white fat and sharply in the more active epididymal ovarian fat.

In animal feeding experiments, the activities of these two enzymes in the adipose tissues fluctuate with how and what the animals were fed. For example, G6PDH activities in animals fed ad libitum were significantly less than in force-fed animals (6). Animals forced to eat intermittently (i.e. "nibble") over a period of time were found to have significantly lower G6PDH and $\mathrm{MDH}$ activities in their adipose tissues than animals fed normally (18, 19). The MDH and G6PDH activities in the fat depot of rats fasted for $96 \mathrm{hr}$ dropped precipitiously, but rose markedly and exceeded prefast levels several fold when the animals were re-fed for the next $96 \mathrm{hr}$ (35). Leveille (18) and Leveille and Hanson (19) have shown that rats fed high carbohydrate diets developed marked elevation in the activities of G6PDH and $\mathrm{MDH}$ in their adipose tissues, whereas those fed diets high in fat exhibited profound reductions in the activities of these enzymes. Animals fed a high carbohydrate diet and forced to "nibble" had lower adipose enzyme activities than animals on high carbohydrate diet who were allowed to eat normally, although not to the extent found in animals which had been fed high fat diets. Nibbling could not further reduce the adipose enzyme activities of animals fed a high fat diet $(18,19)$.

The available data suggest that LDH activities in the adipose tissue of man range between 200 and 2,000 mU (millimicromoles substrate consumed per $\mathrm{mg}$ protein per min); for $\mathrm{MDH}, 20$ and $300 \mathrm{mU}$; and for G6PDH, 0 and $100 \mathrm{mU}$ (7, 8, 23, 29). Comparable data for these enzymes in animals range from 600 to $2,000 \mathrm{mU}$ for $\mathrm{LDH}, 400$ to $3,000 \mathrm{mU}$ for $\mathrm{MDH}$, and 20 to $400 \mathrm{mU}$ for G6PDH $(6,10,13,18,19,21,33,35)$. As previously noted, the highest values seem to be in pigs $(12,13)$.

Problems with interpreting published data arise because investigators have not only employed different assay methods, but sometimes have omitted entirely to specify the substrate. Often enzyme activities have been expressed in different ways as related to weight of tissue, or to the nitrogen. DNA, or protein content, or on the basis of lipid content or per individual cell. In both man and animals, despite these differences, whole adipose tissue has been 
reported to have higher contents of soluble protein than isolated cells $(7,33)$, and the larger adipose cells have been found to have greater amount of protein than the smaller cells (19). Thus, activities expressed per wet weight will tend to underestimate enzyme activity levels, whereas expression per cell may result in overstated levels in smaller cells.

In animals the pentose pathway is quite active in the adipose tissue (17). From studies with labeled glucose-6-phosphate, about $10-20 \%$ of glucose metabolized in the adipose tissue traverses this pathway $(17,24)$. Since G6PDH is the first enzyme in this pathway, it is not surprising that much of it is present in adipose tissue. However, the role of this enzyme in the adipose tissue metabolism in man has not been well delineated since, in adults, adipose G6PDH activity is low to absent $(7,23,29)$, whereas the moderate levels found in neonatal adipose tissue seem to disappear after 3 days of age (23).

Enzyme studies have not been reported for cultured human adipose cells, although Poznanski et al. (25) stated recently that cultured human adipose cell precursors, derived apparently from stromal fibroblasts in the adipose tissue, can be distinguished biochemically from skin fibroblasts. Although their doubling time was the same as that for skin fibroblasts, their rate of glucose incorporation and glycerol production was significantly higher than in skin fibroblasts.

The present study was undertaken to determine whether there are any biochemical characteristics of cultured adipose cells which may add to an understanding of the in vivo metabolic findings which have been discovered to date. It is already known that not only can adipose cells be grown in synthetic medium $(2,3)$ but also, after they have become fat-free in culture, they can be induced to reaccumulate lipids intracellularly when sera of obese patients are added to the medium (1). Interest in measuring LDH as well as $\mathrm{MDH}$ and G6PDH has developed from the observation of Reddi and Huggins (27) that the different tissues of the rat have characteristic $\mathrm{LDH}$ to $\mathrm{MDH}$ ratios, and that the ratio of activities of $\mathrm{LDH}$ to $\mathrm{MDH}$ was characteristic for rat fibroblasts transformed in culture to cartilage and bone.

\section{MATERIALS AND METHODS}

Adipose tissue specimens obtained at laparotomies from 12 children aged $3 \mathrm{hr}-2$ years were immediately processed by the technique described previously (2) and adapted from the method of Rodbell (28). Eight of these specimens were from children $3 \mathrm{hr}-9$ months of age and four from children 1-2 years old. After disaggregation by collagenase the cells were planted in $25-\mathrm{ml}$ plastic flasks (35) containing $3 \mathrm{ml}$ McCoy's $5 \mathrm{~A}$ modified medium supplemented with $20 \%$ fetal calf serum and penicillin $(60 \mathrm{U} / \mathrm{ml})$. and the cultures were incubated at $37^{\circ}$ in gas phase of $95 \%$ air and $5 \% \mathrm{CO}_{2}$. The cultures of the cells from the eight youngest children grew satisfactorily and were subcultured several times, usually every 5-7 days, over a period of 15-30 weeks by the technique of Puck et al. (26). Weekly enzyme assays were done on those eight cultures with actively dividing cells.

Cultures of skin fibroblasts from four normal children aged newborn to 18 years, established at the Medical Genetic Laboratory of the Hospital of University of Pennsylvania and the Clinical Research Center of the Philadelphia General Hospital, were also maintained and subcultured several times, under conditions similar to those described for adipocytes, over a 15-20-week period. These cultures were assayed weekly for enzyme activities at the same time as the adipose cell cultures.

To determine whether any changes occurred in the enzyme activities while the cells were actively storing lipids intracellularly, replicate cultures from three adipose cell lines from the three youngest infants, aged $3 \mathrm{hr}-3$ months, and three skin-fibroblast lines from three newborns were each transferred and maintained for 4 days in "obese serum." The latter was obtained by pooling sera from two very obese children aged 4 and 15 years (Table 1); these sera were separated from whole blood shortly after venipuncture, pooled in equal amounts, stored in the refrigerator at $4^{\circ}$, and used within $24 \mathrm{hr}$. The pool of serum was not processed in any other way. Enzyme assays were done on the first day before obese serum was added, 2 days later, and on the 4th day before synthetic medium replaced the obese serum.

Enzyme assays, as described below, were done on the initial cell isolates after these were washed several times in $0.06 \mathrm{M}$ phosphate buffer, $\mathrm{pH} 7.4$, and homogenized in distilled water. Weekly assays were done of the cultured cells after the cultures had become well established, usually at 4 weeks. From then on 11-25 weekly assays were done depending on how long the cultures continued to thrive. Enzyme assays were done on whole cell lysates prepared by thrice washing the culture flasks and cells thoroughly with large quantities of $0.06 \mathrm{M}$ phosphate buffer, pH 7.4, then lysing the cells in 1 $\mathrm{ml}$ distilled water and rapidly freezing and thawing three to five times. This procedure usually produced an uniform cell lysate.

LDH-P was assayed by the method of Wroblewski and LaDue (34) as revised by Henry et al. (11); G6PDH by the method of Kornberg and Horecker (16); and $\mathrm{MDH}$, using oxalacetate as substrate, by the method of Kitto and Kaplan (15). Protein was assayed by the method of Lowry et al. (20). All enzyme assays were performed in duplicates at $30^{\circ}$ at $340 \mathrm{~nm}$ in a Hitachi digital recording spectrophotometer, model 191.

All cultures were regularly examined under an inverted Nikon microscope MS and photomicrographs were taken on selected cultures with a Nikon Microflex AFM automatic camera.

Adipose cells which have become adapted to culture, which have lost most of their intracellular lipids, which have altered their appearance and look like fibroblasts, and which may or may not be dividing in culture have been termed "adipofibroblasts" in this report.

\section{- RESULTS}

Table I summarizes the profile of the lipid content of the sera from the two obese children used in this study. It should be noted that both sera were different from normal sera in one respect only. The free fatty acid contents were nearly twice as high as the normal value. No assays were done on the levels of various hormones, such as insulin, growth hormone, epinephrine, or glucagon.

Figure 1 is a photomicrograph showing the characteristic signet ring appearance of fat-filled adipose cells. The cytoplasmic materials and nucleus could not be identified by the light microscope. Changes in shape toward an oval appearance could be observed as early as $48 \mathrm{hr}$ after the cells were initially planted, especially in cultures of cells from the youngest infants. Figure 2 shows some cells which had spread but had retained a significant amount of intracellular lipids. By 15-25 days many cells had lost their intracellular lipids entirely. However, many cells still retained considerable amounts of intracellular lipids beyond 25 days. Fig. ure 3 shows some cells which had lost their intracellular lipids by the 27 th day in culture. The process of "delipidization" appears to take longer in cells from the older children. Cell divisions were first seen after the cells have become mostly lipid-free and was limited to cells from the younger infants.

Table 1. Lipid profiles of sera from two obese children ${ }^{a}$

\begin{tabular}{lccc}
\hline & \multicolumn{3}{c}{$\mathrm{mg} / 100 \mathrm{ml}$} \\
\cline { 2 - 4 } & $\begin{array}{c}\text { Subject } 1: \\
\text { male, } 15 \text { years, } \\
180 \mathrm{~kg}\end{array}$ & $\begin{array}{c}\text { Subject 2: } \\
\text { male, 4 years, } \\
51 \mathrm{~kg}\end{array}$ & $\begin{array}{c}\text { Normal } \\
\text { subjects }\end{array}$ \\
\hline Total lipids & 316 & 370 & $370-440$ \\
Phospholipids & 142 & 202 & 143 \\
Cholesterol & 21 & 28 & 20 \\
Free fatty & 30 & 34 & 17 \\
$\quad$ acid & & & \\
Triglycerides & 85 & 52 & 76 \\
Cholesterol- & 82 & 90 & 113 \\
$\quad$ ester & & & \\
\hline
\end{tabular}

\footnotetext{
${ }^{1}$ The sera were pooled in equal amounts before use as growth medium.
} 
Table 2 is a summary of the mean values of specific activities of LDH. MDH, and G6PDH in the isolated cells at the time of initial culture, in adipofibroblasts (fat-free, fibroblast-like adipocytes), and in skin fibroblasts, as measured over a period of 1530 weeks. Although there were slight fluctuations from week to week (Fig. 4), the adipofibroblasts showed remarkable constancy in enzyme activities, once adapted to culture. The enzyme activities of skin fibroblasts were also very constant over the 15-20 weeks they were assayed (Table 2).

For all enzymes assayed, the activities rose as the adipose cells became adapted to the synthetic medium. LDH-P activity tripled as did G6PDH activity, while MDH activity doubled. The activities of LDH-P and G6PDH in adipofibroblasts and skin fibroblasts were similar, whereas the activity of $\mathrm{MDH}$ was

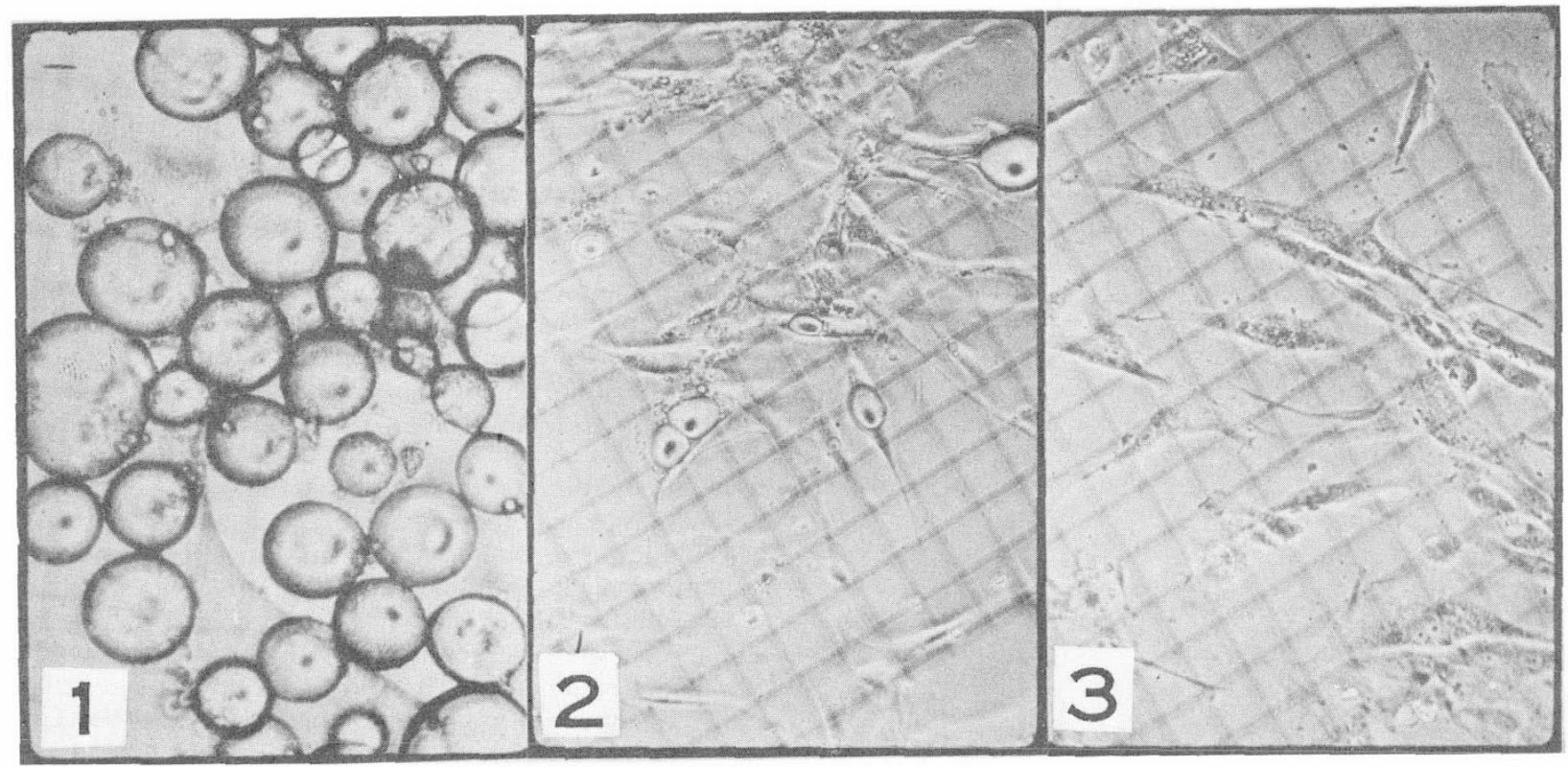

Fig. 1. Freshly isolated adipose cells from the anterior abdominal wall of a 3 -month-old child $(\times 150)$. There is significant variation in the sizes of the cells from the same site.

Fig. 2. Adipocytes from a 2-month-old child; many of the cells have lost their intracellular lipids, others have much of the lipids still present, but all have changed to oval or fibroblast-like appearance. This culture was 17 days old ( $\times 100)$.

Fig. 3. Photomicrograph of the same cells as in Figure 2, 27 days after initial culture and 10 days after Figure 2 was taken. Practically all intracellular lipids have disappeared. These cells are termed adipofibroblasts in this study.

Table 2. Specific activities (millimicromoles of substrate consumed per mg protein per min) of lactate dehydrogenase with pyruvate as substrate $(L D H-P)$, malate dehydrogenase $(M D H)$, and glucose-6-phosphate dehvdrogenase (G6PDH) in adipocites, adipofibroblasts, and skin fibroblasts in artificial medium and obese serum ${ }^{1}$

\begin{tabular}{|c|c|c|c|c|}
\hline \multirow[b]{2}{*}{$\begin{array}{l}\text { Adipocytes at initial } \\
\text { culture }(n=12)\end{array}$} & \multicolumn{2}{|c|}{ Adipofibroblasts } & \multicolumn{2}{|c|}{ Skin fibroblasts } \\
\hline & $\begin{array}{l}\text { Established in } \\
\text { McCoy's medium } \\
(n=8)\end{array}$ & $\begin{array}{l}\text { In obese serum for } \\
4 \text { days }(n=3)\end{array}$ & $\begin{array}{l}\text { Established in } \\
\text { McCoy's medium } \\
(n=4)\end{array}$ & $\begin{array}{c}\text { In obest serum for } \\
4 \text { days }(n=3)\end{array}$ \\
\hline $\begin{array}{l}512^{\mathrm{a}} \\
\pm 43\end{array}$ & $\begin{array}{l}1,740^{\mathrm{a}} \\
\pm 575\end{array}$ & $\begin{array}{l}1,622 \\
\pm 293\end{array}$ & $\begin{array}{l}1,521 \\
\pm 635\end{array}$ & $\begin{array}{l}1,759 \\
\pm 516\end{array}$ \\
\hline $\begin{array}{l}384^{\mathrm{b}} \\
\pm 82\end{array}$ & $\begin{aligned} & 636^{\text {b. c. d }} \\
\pm & 135\end{aligned}$ & $\begin{aligned} & 269^{c} \\
\pm & 106\end{aligned}$ & $\begin{aligned} & 341^{d} \\
\pm & 144\end{aligned}$ & $\begin{array}{r}322 \\
\pm 35\end{array}$ \\
\hline $\begin{aligned} & 5^{\mathrm{e}} \\
\pm & 2\end{aligned}$ & $\begin{aligned} & 50^{\mathrm{e}, \mathrm{b}} \\
\pm & 15\end{aligned}$ & $\begin{array}{l}15^{\mathrm{b}} \\
\pm 4\end{array}$ & $\begin{array}{l}43^{\mathrm{g}} \\
\pm 3\end{array}$ & $\begin{aligned} & 5^{\mathrm{g}} \\
\pm & 1\end{aligned}$ \\
\hline
\end{tabular}

The $t$ test was applied in each pair of comparable situations and only those identified by letters showed the following statistical significance:

\begin{tabular}{lrcl}
\hline & $t$ values & Degrees of freedom & $P$ values \\
\hline a & 81.67 & 7 & 0.001 \\
$\mathrm{~b}$ & 3.55 & 30 & 0.005 \\
$\mathrm{c}$ & 3.34 & 30 & 0.005 \\
$\mathrm{~d}$ & 2.46 & 30 & 0.01 \\
$\mathrm{e}$ & 8.48 & 7 & 0.005 \\
$\mathrm{f}$ & 6.03 & 6 & 0.005 \\
$\mathrm{~g}$ & 17.50 & 1 & 0.025
\end{tabular}


significantly higher in adipofibroblasts than in fibroblasts (Table 2).

Once the adipofibroblasts become adapted to the synthetic medium, there was a remarkable parallel fluctuation noted in the activities of both MDH and LDH-P (Fig. 4).

Figure 5 depicts graphically the effects which growth of adipofibroblasts in obese serum for 4 days had on the activities of LDH-P, MDH, and G6PDH. Although the activities of LDH-P were unchanged, there was a sharp reduction in the activities of $\mathrm{MDH}$ and G6PDH while these cells were being grown in obese serum. Table 2 also shows that the skin fibroblasts, grown in the same obese serum for 4 days, showed a significant reduction only in G6PDH activities but not in the activities of LDHP and MDH.

During the 4 days in obese serum, the adipofibroblasts appeared under the phase contrast microscope to have reaccumulated lipids intracellularly, a finding which has been observed in earlier experiments (1). When these cells were returned to synthetic medium the intracellular lipids disappeared. Miscroscopic obser-

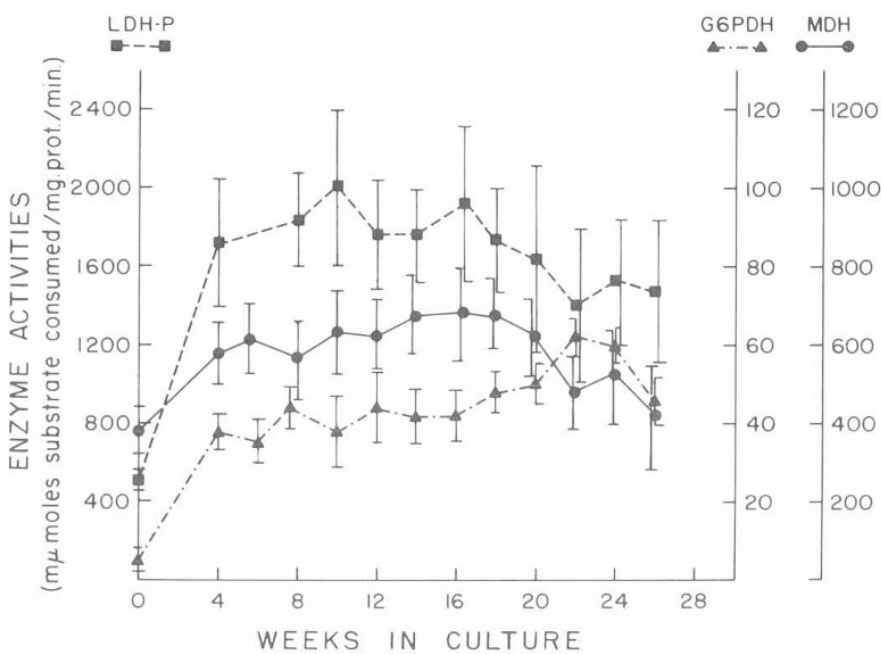

Fig. 4. Levels of activities of lactate dehydrogenase with pyruvate as substrate $(L D H-P)$, malate dehydrogenase $(M D H)$, and glucose-6-phosphate dehydrogenase $(G 6 P D H)$ of cultured adipocytes $(n=8)$ maintained in culture over 26 weeks. The enzyme activities increased significantly during the first 4 weeks and stabilized thereafter for the next several weeks.

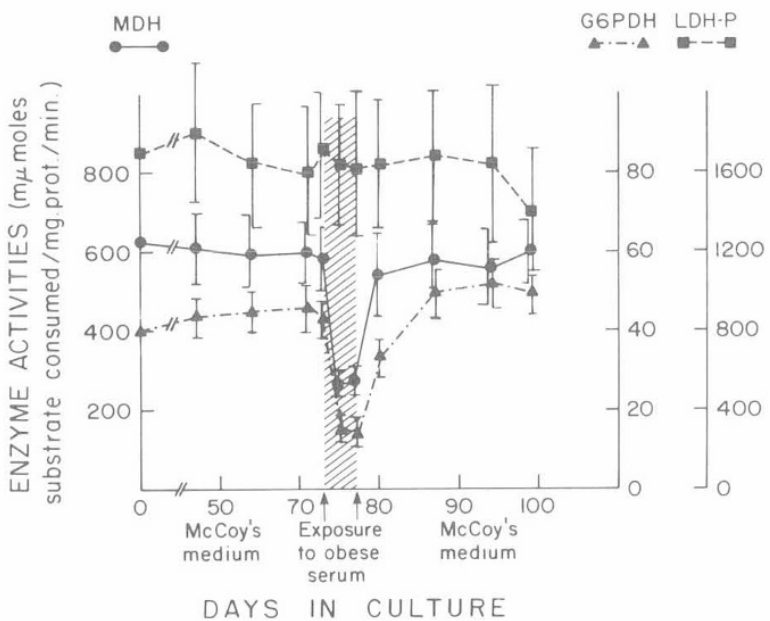

Fig. 5. Mean enzyme activities (lactate dehydrogenase with pyruvate as substrate $(L D H-P)$, malate dehydrogenase $(M D H)$, and glucose-6-phosphate dehydrogenase $(G 6 P D H))$ in cultured adipofibroblasts of three young infants. The effect of growth in obese serum for 4 days after the cells have been well adapted to McCoy's medium for several weeks. Note the sharp drop in levels of MDH and G6PDH and the absence of change in levels of LDH-P. The effect of obese serum on the enzyme activities seemed prompt as did the recovery when McCoy's medium replaced obese serum. vations on skin fibroblasts grown in obese serum for 4 days showed that only a very small amount of intracellular lipids accumulated, and this small amount disappeared when the cells were returned to synthetic medium.

\section{DISCUSSION}

In these tissue culture observations, adipose tissue cells grown in artificial medium developed enzyme patterns which were, in some respects, similar to those of skin fibroblasts grown in the same medium. There were some important differences, however. As adipose cells became transformed in culture from the spherical signet ring, fat-filled forms to the lipid-free adipofibroblasts, activities of G6PDH (a pentose shunt enzyme) and LDH-P (a glycolytic enzyme) rose sharply from relatively low levels to levels comparable with those found in skin fibroblasts, and those of $\mathrm{MDH}$, which were initially comparable with those of skin fibroblasts, rose even higher. However, the behavior of these two cell lines in the obese serum would appear to suggest that they are two completely different types of cells. The activities of G6PDH fell in skin fibroblast exposed to obese serum, whereas the activities of both G6PDH and $\mathrm{MDH}$ fell in adipofibroblasts exposed to the same obese serum.

The enzymatic alterations found in adipofibroblasts grown in obese serum parallel those of adipose tissue in animals which have been fed high fat diets. This finding may suggest that the enzymatic adaptations made by adipose tissue in situ can be achieved by adipose cells in culture and may further suggest that perhaps the same mechanism is responsible in both situations.

It should be noted that the most striking characteristic of the obese sera employed in this study was the elevated free fatty acid content (Table 1). Although the insulin and glucose levels were not measured, obese serum has been reported repeatedly to be hyperinsulinemic and normoglycemic $(4,5,31)$, and it has been presumed that the sera used in this study were also hyperinsulinemic and normoglycemic. One would expect that in the presence of high insulin, normal glucose, and high free fatty acid contents (assuming the cultured adipofibroblasts may have retained their insulin sensitivity $(9,14,30)$, these cells would become more active in synthesis and storage of lipid. This, in fact, was observed in this study. Under the conditions defined here, (high free fatty acid, normal glucose, and high insulin) a reduction in the levels of enzymes needed for fatty acid synthesis might be expected, as was observed in this study. It is reasonable to speculate, although they were not measured in this study, that enzymes involved in lipid transport across cell membranes and in triglyceride synthesis were probably also enhanced in activity. With glucose and insulin available in sufficient quantities, the production of glycerophosphate was probably accelerated, thereby increasing the supply of backbone ingredient needed to esterify the large quantity of free fatty acids available. Since only one glycolytic enzme (LDH-P) was measured, and its activity did not change, it is not possible to comment on whether this, in fact, did happen; this possibility will be pursued in later studies.

It is possible that other active substances in the sera of obese patients contributed to the ability of these sera to induce adipofibroblasts to synthesize and store triglycerides. The role of several hormones, such as glucagon, growth hormone, epinephrine, and others, in lipolysis in adipose cells have been described $(4,14,28)$. That these adipocytes behaved lipogenically in obese serum would suggest that, on balance, obese serum contains more lipogenically active than lipolytically active factors. We expect to look at these factors in considerably greater detail in future studies.

We confirmed the earlier findings by others $(7,23,29)$ in human adipose tissue that the activities of G6PDH is low to nonexistent. yet in animal adipose tissue, the activity of this enzyme is significant. It is reasonable to expect human adipose tissue, with its need for NADPH and lipid precursors, to have a more active pentose pathway than has been shown so far. However, it is possible also that other pathways for the generation of NADPH and fatty acid precursors are more important than the pentose pathway in human adipose tissue. It is important to note that 
citrate-cleaving enzymes and malate enzymes are present in significant quantities in human adipose tissue $(8,29)$. These enzymes are also important in lipid synthesis.

The levels of activities of the enzymes in skin fibroblasts remained remarkably constant throughout the period of study. This finding confirms that fibroblasts are differentiated cells. Mellman and Kohn (22) have reported that one of the major characteristics of differentiated cells is that, in culture, they retain a constant level of genetically determined characteristics over a long period of time. However, it was clear that the process of differentiation has not programmed skin fibroblasts to perform the specialized function of lipid synthesis and storage, for when these cells were grown in obese serum which induces lipid synthesis and storage in adipose cells, they failed to store any significant quantities of neutral lipids.

Many questions remain to be answered before clinical problems related to obesity can be understood and intelligently approached. The contributions which can be made by the use of tissue culture and biochemical analyses of cultured cells are potentially great For example investigations currently going on include studies of the effect of sera of young nonobese children on adipose cell division in culture. It may be possible to answer the question about whether or not replicating factors(s) are present in the sera of some children and not in the sera of others. There is, at present, no information on this question.

While confronting the patient whose obesity has led him to seek medical help, the physician may become overwhelmed. It could well be that efforts to influence the number of adipose cells in a given individual or to influence satiation and control obesity in those already plagued by adipose cellular hyperplasia may need to focus on finding a physiologically feasible metabolic interference with the mechanism of adipose cellular division on the one hand or fatty acid synthesis on the other. With respect to the latter. preliminary reports (32) suggest that (-)hydroxycitrate appears, in rats, to diminish the conversion of carbohydrate to lipids by decreasing in vivo fatty acid synthesis by acting as a competitive inhibitor to ATP citrate lyase-CoA. Administering this substance chronically to rats has been reported to produce a dose-dependen inhibition of lipogenesis, appetite reduction, and reduced body weight. By studying key metabolic processes in glucose and fatty acid metabolism in adipose cells over a period of time and under different conditions such as are possible in tissue culture, it may be possible to develop a better understanding of the problem of obesity and other diseases of adipose tissues.

\section{SUMMARY}

Assays of LDH, MDH, and G6PDH on cultured human adipocytes and skin fibroblasts suggest that they are significantly different cells. That these adipocytes are specialized differentiated cells is suggested by the enzymatic adaptations which are observed to occur paralleling the metabolic states of these cells depending on whether they are hydrolyzing or synthesizing and storing triglycerides intracellularly.

\section{REFERENCES AND NOTES}

1. Adebonojo, F, O.: Synthesis and storage of lipids by cultured adipocytes of human neonate: Effects of sera from obese and non-obese human adults. Biol. Neonate, 23: 366 (1973)

2. Adebonojo, F. O.: Monolayer cultures of disaggregated human adipocytes. In Vitro, 11: 50 (1975)

3. Adebonojo, F. O.: Studies on human adipose cells in culture: Relation of cell size and cell multiplication to donor age. Yale J. Biol. Med., 48: 9 (1975).

4. Bray, G. A., Davidson, M. B., and Drenich, E. J.: Obesity: A serious symptom. Ann. Int. Med.. 77: 779 (1972).

5. Brook, C. G. D., and Lloyd, J. K.: Adipose cell size and glucose tolerance in obese children and effects of diet. Arch. Dis. Childhood, 48: 301 (1973).

6. Cohn, C., and Joseph, D.: Effect of rate of ingestion of diet on hexosemonophosphate shunt activity. Amer. J. Physiol., 197: 134? (1959).

7. Englehardt, A., Gries, F. A.. Preiss, H., and Jahnke, K.: Vergleichende untersuchungen uber protein and lipidgehalt und die aktivitaten von enzymen der glykolyse und des pentosephosphat shunts in fettgewebe und in isolierten fettzellen stoff wechselgesunder. Hormone Metab. Res.. 1: 228 (1969).
8. Galton, D. J.: Lipogenesis in human adipose tissue. J. Lipid Res., 9: 19 (1968).

9. Gries, F. A.., and Steinke, J.: Comparative effects of insulin on adipose tissue segments and isolated fat cells of rat and man. J. Clin. Invest. 46:1413 (1967).

10. Hahn, P., and Skala, J.: Changes in interscapular brown adipose tissue of the rat during perinatal and early postnatal development and after cold acclimation. IJI. Some cytoplasmic enzymes. Comp. Biochem. Physiol., 4/B: 147 (1972).

11. Henry, R N Chiamori J N Golub, O J and German, S: Revised spectrophotometric methods for the determination of glutamic oxaloacetic transaminase, glutamic pyruvate transaminase and lactic acid dehydrogenase Amer. J. Clin. Path., 34:381 (1960)

12. Hood, R. L and Allen C. E. Lipogenic enzyme activity in adipose tissue during growth of swine with different propensities to fatten. J. Nutr., 103: 353 (1973).

13. Hood. R. L., and Allen. C. E.: Comparative methods for the expressions of enzyme data in porcine adipose tissue. Comp. Biochem. Physiol.. 44B: 677 (1973).

14. Jacobson, B., and Smith, U.: Effect of cell size on lipolysis and antilipolytic action of insulin in human fat cells. J. Lipid. Res., 13: 651 (1972).

15. Kitto. G. B.. and Kaplan. N. D.: Purification and properties of chicken heart mitochondrial and supernatant malic dehydrogenases. Biochemistry, 5:3966 (1966)

16. Kornberg, A., and Horecker, B. L.: Glucose 6 phosphate dehydrogenase Methods Enzymol. 1: 323 (1955).

17. Landau, B. R., and Katz, J.: Pathways of glucose metabolism. In: A. E. Renold and G. F. Cahill, Jr.: Handbook of Physiology. Sect. 5. Chapt. 25, p. 253 (The Williams \& Wilkins Co., Baltimore, 1965).

18. Leveille, G. A.: Influence of dietary fat and protein on metabolic and enzymatic activities in adipose tissue of meal fed rats. J. Nutr., 91: 25 (1967).

19. Leveille, G. A., and Hanson, R. W.: Adaptive changes in enzyme activity and metabolic pathways in adipose tissue from meal-fed rats. J. Lipid Res., 7: 46 (1966).

20. Lowry. O. H.. Rosebrough, N. J., Farr, A. L., and Randall, R. J.: Protein measurement with the Folin phenol reagent. J. Biol. Chem., 193: 265 (1957).

21. Martin. R. J.. Welton, R. F.. and Baumgardt. B. R.: Adipose and liver tissue enzymes profiles in obese hyperglycemic mice. Proc. Soc. Exp. Biol. Med., 142: 241 (1973).

22. Mellman, W. J., and Kohn, G.: Human cell cultures: Their use in the investigation and diagnosis of disease. Med. Clin. N. Amer.. 54: 701 (1970).

23. Novak, M. Hahn, P. Penn., D. Monkus, E., and Kirby, L. Metabolism of subcutaneous adipose tissue in the immediate postnatal period of human newborns: Developmental changes in some cytoplasmic enzymes. Biol. Neonate, 23: 19 (1973)

24. Plaut, J. P., and Ball, E. G.: Pathways of glucose metabolism. In: A. E. Renold and G. F. Cahill, Jr.: II. Handbook of Physiology. Sect. 5. Chapt. 26, p. 273 (The William \& Wilkins Co., Baltimore, 1965).

25. Poznanski, W. J., Waheed, I., and Van, R.: Human fat cell precursors: Morphologic and metabolic differentiation in culture. Lab. Invest., 29: 570 (1973).

26. Puck, T. T., Ciecuira, S. J., and Fisher, H. W.: Clonal growth in vitro of human cells with fibroblast morphology: Comparison of growth and genetic characteristics of single epithelioid and fibroblast-like cells from a variety of human organs. J. Exp. Med.. 101: 148 (1957).

27. Reddie, A. H., and Huggins, C.: Lactic/malic dehydrogenase quotients during transformation of fibroblasts into cartilage and bone. Proc. Soc. Exp. Med. Biol., 137: 127 (1971).

28. Rodbell, M.: Metabolism of isolated fat cells. I. Effects of hormones on glucose metabolism and lipolysis, J. Biol. Chem., 239: 375 (1964).

29. Schmidt. E.. and Schmidt. F. W.: Enzym-Muster menschlicher gewebe. Klin. Wochschr., 38: 957 (1960).

30. Smith, U.: Effect of cell size on lipid synthesis by human adipose tissue in vitro. J. Lipid Res., 12:65 (1971)

31. Stern, J. S., Batchelor, B. R.. Hollander, N., Cohn, C. K.. and Hirsch, J.: Adipose cell size and immunoreactive insulin levels in obese and normal weight adults. Lancet, ii: 948 (1972)

32. Sullivan, A. C.: (-)Hydroxycitrate: A Metabolic Control of Obesity. Paper delivered at a conference on Obesity-mechanisms, prevention and treatment. University of South Florida College of Medicine, Tampa, Florida, February 6. 1975.

33. Weber, G. Hird, H J Stamm, N. B and Wagle. D S. Enzymes involved in carbohydrate metabolism in adipose tissue. In: A. E. Renold and G. F. Cahill, Jr.: Handbook of Physiology, Sect. 5, Chapt. 23, p. 225 (The Williams \& Wilkins Co., Baltimore, 1965).

34. Wroblewski, F., and LaDue, J. S.: Lactic dehydrogenase activity in blood. Proc. Soc. Exp. Biol. Med., 90: 210 (1955).

35. Young. J. W., Shrago, E., and Lardy, H. A.: Metabolic control of enzymes involved in lipogenesis and gluconeogenesis. Biochemistry, 3: 1687 (1964).

35. Falcon Plastics, Los Angeles, Calif.

36. I am grateful to the Joseph Stokes, Jr., Research Institute of the Children's Hospital in Philadelphia for supporting this work. I thank Ms. Geneva Jackson, Deartment of Medical Genetics, University of Pennsylvania, for supplying the skin fibroblast cultures from the three neonates and $\mathrm{Dr}$. Barbara Howard, Clinical Research Center, Philadelphia General Hospital, for providing the skin fibroblast culture from the 18 year old and for performing the lipid profile analyses on the sera of the two obese children used in this study. The help of Mr. Victor Battles, is gratefully acknowledged. I also thank Jean Cortner, M.D., and Irving Wolman, M.D. for reviewing this paper.

37. Requests for reprints should be addressed to: F. O. Adebonojo, M.D., Rebound Health Center, 1427 Catharine St. Philadelphia, Pa. 19146 (USA).

38. Accepted for publication July 16, 1975. 